\section{Førerkort \\ i grisgrendte strøk}

Jeg er nevrolog i Nord-Trøndelag, som er et fylke med spredt bosetting. De som bor i tettsteder har som regel en hytte et eller annet sted. Offentlige kommunikasjoner er mangelvare, ofte kun skolebuss to ganger per dag i skoleåret. Mange bor langt unna butikk og offentlige servicekontorer, og er i praksis avhengig av egen bil for å kunne ha et sosialt liv.

Tidligere kunne man seponere epilepsimedikasjon med forsiktighet med tanke på bilkjøring under nedtrapping. Jeg pleide å ha en god dialog med mine pasienter i så måte. Nå skal man ilegge pasientene kjøreforbud under nedtrappingen pluss i ytterligere seks måneder; i praksis betyr det ofte ett år uten førerkort. Dette skal også meldes Fylkeslegen (1). De nye forskriftene har forårsaket debatt $\mathrm{i}$ Tidsskriftets spalter (2-4), men få har berørt konsekvensene av dette for pasienter i distriktet.

Det er ingen i Nord-Trøndelag som frivillig gir fra seg førerkortet $i$ et år. Det betyr at det skal mye til før en pasient frivillig vil trappe ned med tanke på seponering av epilepsimedisinene. Mange vil derfor velge å fortsette med medisin selv om de hadde greid seg uten. Det blir nok mange som av den grunn bruker medisiner unødig. Har noen gode forslag til en annen praksis?

\section{Ole-Petter Dah}

Sykehuset Namsos

Ole-Petter Dahl (f. 1952) er spesialist i nevrologi og arbeider $50 \%$ som overlege ved Nevrologisk avdeling, Sykehuset Namsos og $50 \%$ som privatpraktiserende nevrolog i Namsos, med avtale.

Ingen oppgitte interessekonflikter.

Litteratur

1. Regler og veiledning for utfylling av helseattest for førerkort - IS-1437. www. helsedirektoratet.no/ publikasjoner/veiledere/f_rerkort_regler_og_ veiledning for utfylling av helseattest for f rerkort 68087 (13.7.2011).

2. Lossius R, Nakken KO, Brodtkorb E. Endrede helsekrav for førerkort ved epilepsi. Tidsskr Nor Legeforen 2011: 131: 1283-4.

3. Steen T, Knapskog A. Førerkort og anfall med bevissthetstap. Tidsskr Nor Legeforen 2011; 131: 2110.

4. Lossius R, Nakken KO, Brodtkorb E. Epilepsi og førerkort. Tidsskr Nor Legeforen 2011: 131: 2335.

\section{RETTELSER}

Maktskiftet

Stine Bjerkestrand

Tidsskr Nor Legeforen 2012; 132: 125

I lederen i Tidsskriftet nr. 2/2012 s. 125 skal

fjerde avsnitt begynne slik: Dagen etter,

20. oktober, slippes Jørgen Jelstads bok De bortgjemte - om hvordan ME ble vår tids mest omstridte sykdom (9). Jelstad har fulgt Fluge og medarbeidere tett mens de gjennomførte studien

Oppslagsdato på referanse 1,2 og 3 skal være 16.1.2012

Vi beklager feilen. Den er rettet i nettutgaven.

Kun talespråk eller også tegnspråk?

Frank Becker

Tidsskr Nor Legeforen 2012; 132: 136

I Tidsskriftet nr. 2/2012 s. 136 skal stå: Oppgitte interessekonflikter: Forfatteren har fått betalt for fagvurdering av den i kommentaren omtalte rapporten.

Vi beklager feilen. Den er rettet i nettutgaven. 